\title{
The Welfare Implication of an Expansion of an Industrial Zone
}

\author{
Kazuhiro Tetsu \\ Shizuoka University
}

\begin{abstract}
The main objectives of this paper are to present a model introducing the idea of two isolated areas that have different economic features and to analyze the effects of an expansion of an industrial zone. In this model, we assume that there are two areas: one is under full employment, the other is suffering from urban unemployment. In such a two isolated area model, we show that the economic development of a rural area is attained at the cost of an urban area and that national income depends on the endowment of labor force in each area.
\end{abstract}

- JEL Classifications: O18, F10

- Key Words: Industral Zone, Export Processing Zone, Two-area Model

\section{Introduction}

Many developing countries changed their course to the export oriented industrialization while the import substitution industrialization came to the deadlock. One of the means was the establishment of export processing zones (EPZs). Many developing countries considered that the establishment of EPZs was a good policy, because it was able to execute the protection of domestic industries and the export promotion policy simultaneously.

Policymarkers in developing countries believe that the establishment of EPZs brings the host country various benefits, such as an increase in employment, a contribution to acquiring foreign currency and transfers of new technology. As the result of them, policymakers expect that national income may increase.

\footnotetext{
*Corresponding address: Kazuhiro Tetsu, Department of Economics, Shizuoka University, 836 Oya Shizuokashi 422-8529 Japan, Tel.: +81-54-238-4514, Fax.: +81-54-237-1195, E-mail: tetu@ hss.shizuoka.ac.jp (C)2001-Center for International Economics, Sejong Institution, All Rights Reserved.
} 
Since 1970's, many developing countries set about establishing EPZs. While the theoretical analyses which originated with Hamada (1974) using a 2 by 2 model lead to negative conclusions against develpoping countries' expectations, the international organizations such as ILO/UNCTC (1988) and World Bank (1992) support the establishment of EPZs for economic development. In particularly, Asian countries obtained good results. EPZs for played an important role in Asian countries as a first step toward introducing foreign investment. It is also conceivable that industrial zones that spread the fruits of EPZs over domestic economies play an important role in Asian rapid growth since 1980's.

An industrial zone is the important means of attracting foreign investment, and it means a huge area that includes an EPZ in itself. In recent years, the government authorities in many Asian countries have developed industrial zones to abolish earnings differentials between rural and urban areas.

In the present paper, we analyze the effects of an expansion of industrial zones on developing economies. As we stated the above, there are some theoretical studies on EPZs, which originated with Hamada (1974) and extended the earlier models by introducing Harris-Todaro (1970) type unemployment. ${ }^{1}$ However, there are no studies that focus on an establishment of industrial zones undertaking the development of rural areas to abolish earnings differentials between rural and urban areas.

In the past studies on EPZs, Miyagiwa (1993) addresses the issue of where to

\footnotetext{
${ }^{1}$ Hamada (1974) concludes that national income at international prices would decrease when foreign investments increased in the duty-free zone. Rodriguez (1976) extends Hamada's model by introducing capital mobility between two sectors, and shows the host country will attain the same level of welfare that can be achieved under a free trade regime. Hamilton and Svensson (1982) paid attention to the location to introduce foreign investments and concluded that introducing foreign investment into a dutyfree zone deteriorated national welfare more than introducing the same amount of foreign investment into a domestic zone. Young (1987) is also a 2 by 2 model, but it supposes that good 1 is produced in a domestic industry and good 2 is produced in a duty-free zone. In his model, a duty-free zone expands by a tariff reduction of imported intermediate goods or a tax reduction of foreign capital, and he shows the possibility that an expansion of a duty-free zone increases national income under a certain condition. Miyagiwa (1986) consists of three sectors, namely, two domestic sectors and one free-trade zone. He considers that free-trade zones are often established by government subsidies designed to promote nontraditional exports, and examines how the expansion of a free-trade zone that results from an increase in an export subsidy affects national income. Other extensions of the earlier models are to introduce a Harris-Todaro (1970) type unemployment. Young and Miyagiwa (1987), which is also a three-sector model, pays attention to mass urban unemployment. They conclude that the tariff reduction of an intermediate good accompanying the establishment of a duty-free zone increases national income at world prices. Chaudhuri and Adhikari (1993) introduce inter-sector capital mobility into the YoungMiyagiwa model, but they conclude that the welfare effects of an expansion of an EPZ are ambiguous.
} 
locate EPZs in a developing country and reveals that the rural area is likely to be a better location for EPZs. Many rural based EPZs, however, go wrong in practice. In Basu (1996), the establishment of rural based EPZs through a subsidy to either domestic or foreign capital reduces the level of unemployment and worsens national income under certain conditions. In their models, it is supposed that labor force can move between a rural area and an urban area. This means that the rural area neighbors the urban area. It is thought, however, that the assumption of labor mobility between two areas is not suitable for the analysis of industrial zones because government authorities in developing countries, especially ASEAN, have been exploiting industrial zones to develop a rural area which is far and isolated from an urban area. In this case, the rural area exists as an economic enclave. Thus, it seems reasonable to suppose that there is no labor migration between the two areas. In our model, we suppose that there are two isolated areas that have distinctive economic features. In the rural area where an industrial zone is developed, full employment will be attained. On the other hand, in the urban area, mass urban unemployment will remain. Considering the type of economy in developing countries with industrial zones, therefore, we believe that it is important to build a model including two isolated areas. Our model may also apply to the analysis of special economic zones in China where labor migration between areas is prohibited by law.

In the present paper, the main objective is to present a model introducing the idea of two isolated areas and to examine the effects of a development strategy in which policymakers in developing countries develop an industrial zone. The results are interesting. Though the only link between the two areas is the supply and demand for intermediate goods and there is no labor migration between the two areas, the development of an industrial zone in the rural area affects labor mobility in the urban area and increases urban unemployment. ${ }^{2}$ We also show that it decreases income in the urban area while it increases income in the rural area. This means that the purpose of the development of a rural area is attained at the cost of an urban area. An interesting result, moreover, that national income depends on the endowment of labor in each area.

\footnotetext{
${ }^{2}$ Din (1994) focuses on the backward linkages between a domestic areas and an EPZ. His model with three sectors incorporates an intermediate goods-producing sector, and shows that if the intermediate good is non-traded, then there are possibilities for improvement in national income as a result of increased foreign investment in an EPZ.

${ }^{3}$ We assume that an expansion or development of an industrial zone is led with a tariff reduction on imported intermediate goods as in Young (1987) and Young-Miyagiwa (1987).
} 
In section 2, we first present a two isolated area model, and in section 3 we consider the effects of a development of an industrial zone on unemployment and income. ${ }^{3}$ In section 4 we conclude this paper.

\section{The Model}

We consider a small open economy. This country is divided into two areas: an urban area and a rural area. The urban area consists of large firms and small enterprises. In this area, there is unemployment. The large firms produce goods, $M$, with domestic capital and labor. The small enterprises produce goods, $A$, with domestic labor, capital and intermediate goods which are produced in and transferred from the rural area. The prices of these goods, $P_{M}$ and $P_{A}$, are given internationally because of the small open economy assumption. On the other hand, the rural area consists of foreign firms in an industrial zone and small farms, but there is no unemployment in this area. The foreign firms in the industrial zone produce goods, $f$, with domestic labor, foreign capital and imported intermediate goods which are traded at a given international price, $P_{f}$. The small farms produce goods, $g$, with domestic labor only, and they are supplied to small enterprises in the urban area as intermediate inputs. ${ }^{4}$

Assuming that all markets are perfectly competitive and that there are constant returns to scale, we can express the zero profit conditions with unit cost functions, $C^{i}(i=M, A, f)$, as:

$$
\begin{gathered}
P_{M}=C^{M}(\bar{W}, R) \\
P_{A}=C^{A}\left(W_{A}, R, P_{g}\right) \\
P_{f}=C^{f}\left(W_{g}, r^{*}, P_{e}+t\right) \\
P_{g}=\alpha W_{g}
\end{gathered}
$$

where $\alpha$ is the exogenously given technological coefficient for small farms, $P_{g}$ is the price of the agricultural good for the small farms, $\bar{W}$ is the urban wage rate which is institutionally fixed at a higher level than the prevailing wage rate $\left(W_{A}\right)$ for small enterprises, $R$ is the return to domestic capital, $W_{g}$ is the competitive wage rate prevailing in the rural area, $r^{*}$ is the world market return to capital specific to the foreign firms, $P_{e}$ is the price of the imported intermediate good, and $t$ is the tariff rate

\footnotetext{
${ }^{4} \mathrm{We}$ assume that food is supplied to households through small enterprises in the urban area.
} 
on the imports of the intermediate good for the foreign firms, respectively.

This country consists of the above two areas, but we assume that there is no labor migration between the two areas as I mentioned in the introduction. The urban area has an endowment of labor, $\overline{L_{1}}$, and it is a Harris-Todaro world, namely, urban unemployment exists there. The rural area has an endowment of labor, $\overline{L_{2}}$, but there is no unemployment. Thus we can express equilibrium in the labor markets as

$$
\begin{gathered}
C_{W}^{M} X_{M}+C_{W}^{A} X_{A}+v=\bar{L}_{1} \\
C_{W}^{f} X_{f}+C_{W}^{g} X_{g}=\bar{L}_{2}
\end{gathered}
$$

where $X_{i}$ is the output in the $i$ th activity $(i=M, A, f, g), v$ is the level of unemployment, $C_{j}^{i}$ is the partial derivative of the $i$ th unit cost function with respect to the $j$ th factor price $(j=W, R, P)$.

Labor in small enterprises tries to move to large firms in order to get the better working conditions and the higher wage. In accordance with the Harris-Todaro model, labor movement in the urban area is governed by expected wage equalization. Thus, for equilibrium in labor movement, we can write down the following equations,

$$
W_{A}=\bar{W} C_{W}^{M} X_{M} /\left(C_{W}^{M} X_{M}+v\right)
$$

The full employment condition for domestic capital can be written as

$$
C_{R}^{M} X_{M}+C_{R}^{A} X_{A}=\bar{K}
$$

where $\bar{K}$ is the endowment of inelastically supplied domestic capital.

The equilibrium condition in the market for the agricultural sector's output can be expressed as

$$
C_{P}^{A} X_{A}=X_{g}
$$

Thus, our model consists of nine equations (1)-(9) which include nine unknowns, $W_{a}, W_{A}, R, P_{g}, X_{M}, X_{A}, X_{g}, X_{f}, v$.

\section{An Expansion of the Industrial Zone}

In this section, we analyze the effects on unemployment in the urban area, and

\footnotetext{
${ }^{5}$ We can show easily that $d X_{f} / d t<0$.
} 
income, when the industrial zone expands further with a tariff reduction on imported intermediate goods. ${ }^{5}$

\section{A. Unemployment}

In this model, given $P_{f}$ and $t$, eq. (3) determines $W_{g}$ and eq. (4) determines $P_{g}$. Given $\bar{W}, P_{M}$, yields $R$. Eq. (2) then yields $W_{A}$. Differentiating eq. (7) with respect to $t$ yields

$$
d v / d t=-\left[\left(C_{W}^{M} X_{M}+v\right) / W_{A}\right]\left(d W_{A} / d t\right)
$$

The tariff reduction on the imported intermediate good in the industrial zone increases the level of unemployment in the urban area because of $d W_{A} / d t>0$.

Proposition 1. Unemployment in the urban area increases when the industrial zone in the rural area expands further with the tariff reduction on the imported intermediate good.

The above result can be explained as follows. If a reduction of tariff on an imported intermediate good is carried out, the foreign firm in the industrial zone uses more of the imported intermediate good. Consequently, the demand for labor increases in the industrial zone. Because the tariff reduction on the imported intermediate good raises the wage in the rural area, $W_{g}$, labor is released from the small farm to the industrial zone. Therefore, output in the industrial zone increases and output in the small farm decreases. On the other hand, the tariff reduction on the imported intermediate good affects labor movement in the urban area through a rise in the price of the intermediate good which is produced in the small farm. Because of the rise in the price of the domestically produced intermediate good, the wage in the small enterprise, $W_{A}$, decreases. The decrease in the wage, $W_{A}$, means that the expected wage in the large firm rises relatively. Consequently, labor in the small enterprise tries to move to the large firm. However, because the tariff reduction on the imported intermediate good does not affect factor prices in the large firm, the amount of labor employed in the large firm is kept constant. Thus the labor attempting to move from the small enterprise to the large firm is absorbed into the pool of the unemployed, and the level of unemployment in the urban area rises.

\section{B. Income}

Can our model support the host country's expectations that earnings differentials between rural and urban areas are abolished and national income increases when 
an industrial zone expands? First, we examine the effects on income in the urban and rural areas, then on national income.

Income in the urban area equals payments to domestic factors. Thus we can express income in the urban area, $Y_{1}$, as

$$
Y_{1}=\bar{W} L_{M}+W_{A} L_{A}+\bar{K} L
$$

where $L_{M}, L_{A}$ are the amounts of labor employed in the large firm and the small enterprise, respectively. On the other hand, because the rental to foreign capital, $r^{*}$, is fully repatriated abroad, the rural area acquires payments to the domestic factor, labor, and tariff revenue. However, the tariff revenue is not counted among payments in the rural area. The income in the rural area, $Y_{2}$, therefore, is

$$
Y_{2}=W_{a}\left(L_{f}+L_{g}\right)
$$

where $L_{f}, L_{g}$ are the amounts of labor employed in the industrial zone and the small farm, respectively. Eqs.(11), (12) can be restated with eqs.(5), (6) and (7) as

$$
\begin{gathered}
Y_{1}=W_{A} \bar{L}_{1}+\bar{K} R \\
Y_{2}=W_{a} \bar{L}_{2}
\end{gathered}
$$

Differentiating (13), (14) with respect to $t$,

$$
\begin{gathered}
d Y_{1} / d t=\bar{L}_{1}\left(d W_{A} / d t\right)+\bar{K}(d R / d t) \\
d Y_{2} / d t=\bar{L}_{2}\left(d W_{g} / d t\right)
\end{gathered}
$$

We can show easily that $d W_{g} / d t<0, d W_{A} / d t>0, d R / d t=0$. Therefore we obtain $d Y_{1} / d t>0$ and $d Y_{2} / d t<0$.

Proposition 2. When the industrial zone expands with a tariff reduction on the imported intermediate input, income in the urban area decreases and increases in the rural area.

The economic interpretation is as follows. A reduction in the tariff on intermediate goods does not affect the return to capital specific to the large firm $(d R / d t=0)$. On the other hand, the return to foreign capital, $r^{*}$, is fully repatriated. Thus the change of income in the urban area and the rural area is measured in terms of the change of labor's earnings. At constant output price in the industrial zone, while the tariff reduction raises the wage in the rural area $\left(d W_{g} / d t<0\right)$, it makes the wage lower in the small enterprise through a rise in the price of domestically produced intermediate goods $\left(d W_{A} / d t>0\right)$. Therefore, income in the 
urban area decreases and increases in the rural area.

Next, we examine the effect on national income. In this model, national income consists of income in the urban area, the rural area and the tariff revenue on imported intermediate goods. Thus national income is expressed as follows.

$$
\begin{gathered}
Y=Y_{1}+Y_{2}+G t \\
=\bar{W} L_{M}+W_{A} L_{A}+\bar{K} R+W_{g}\left(L_{a}+L_{f}\right)+t G \\
=\bar{L}_{t} W_{A}+\bar{L}_{2} W_{g}+\bar{K} R+t G
\end{gathered}
$$

where $G$ denotes the demands for imported intermediate goods in the industrial zone $\left(G=C_{P}^{f} X_{f}\right)$. Differentiating (17) with respect to $t$ yields

$$
d Y / d t=\bar{L}_{1}\left(d W_{A} / d t\right)+\bar{L}_{2}\left(d W_{g} / d t\right)+\bar{K}(d R / d t)+G+t(d G / d t)
$$

We have already shown that $d W_{A} / \mathrm{dt}>0, d W_{g} / d t<0$ and $d R / d t=0$. Assuming the initial tariff is small, we obtain the following proposition:

Proposition 3. When the industrial zone expands with a tariff reduction on the imported intermediate input, the following condition is sufficient to guarantee a decrease in national income.

$$
\theta_{P A} / \theta_{W A}>\bar{L}_{2} W_{g} / \bar{L}_{1} W_{A}
$$

where $\theta_{P A}, \theta_{W A}$ are the value shares of intermediate input and labor in the small enterprise, respectively.

Because a tariff reduction on an imported intermediate good in the industrial zone makes the wage in the urban area lower and the one in the rural area higher, if the developing country has a huge labor force in the urban area than in the rural area, the likelihood that national income will decrease as a result of industrial zone expansion becomes great. Similarly, the bigger the value share of intermediate input or the smaller that of labor, the stronger the likelihood that the same thing occurs.

\section{Conclusion}

We have showed a model introducing the idea of two isolated areas and examined the welfare implications of an expansion of an industrial zone. Our two isolated area model gives us some interesting results: in a developing country, a policy of attracting foreign investments into industrial zones, this means a tariff 
reduction on imported intermediate inputs in a industrial zone in this model, always makes the rural area develop as policymakers expected. On the other hand, the development of the industrial zone increases urban unemployment and makes the urban area poorer. Thus, the expansion of the industrial zone in the rural area may be a means to develop the undeveloped rural area at the cost of the developed urban area. However, it does not always decreases the national income. Whether the national income increases or not depends on the endowment of labor in the urban and rural area.

Finally, Young and Miyagiwa (1987) remarked that a common motive for setting up an EPZ was high domestic unemployment in the urban area. In our result, however, setting up the industrial zone in the rural area is not a good policy for reducing urban unemployment in developing countries.

\section{Acknowledgement}

I am deeply indebted to Professor Hiroshi Ohta for his helpful comments and suggestions. I also would like to thank two anonymous referees for their valuable comments. Any remaining errors are solely my responsiblity.

Date accepted: March 2001

\section{References}

Basu, A. K. (1996), "Unemployment Reduction in the Presence of a Rural Based Free Trade Zone: Some Policy Implications." Journal of Economic Integration 11, 453-477 Chaudhuri, T. D. and Adhikari, S. (1993), "Free Trade Zones with Harris- Todaro Unemployment -A note on Young-Miyagiwa-," Journal of Development Economics 41, 157-162.

Din, M. (1994), "Export Processing Zones and Backward Linkages," Journal of Development Economics 43, 369-385.

Hamada, K. (1974), "An Economic Analysis of the Duty-free Zone," Journal of International Economics 4, 225-241.

Hamilton, C. and Svensson, L. (1982), "On the Welfare Effects of a 'Duty Free' Zone, Journal of International Economics 13, 45-64.

Harris, J. R. and Todaro, M. (1970), "Migration, Unemployment and Development: A two Sector Analysis," American Economic Review 60, 126-142.

ILO/UNCTC (1988). "Economic and Social Effects of Multinational Enterprise in Export

Processing Zones" Geneva: International Labor Organization. 
Miyagiwa, K. (1993), "The Locational Choice for Free-Trade Zones -Rural versus urban options-," Journal of Development Economics 40, 187-203.

Rodriguez, C. A. (1976), “A Note on the Economics of the Duty Free Zone," Journal of International Economics 6, 385-388.

Young, L. (1987), "Intermediate Goods and the Formation of Duty-Free Zones," Journal of Development Economics 25, 369-384.

Young, L. and Miyagiwa, K. (1987), "Unemployment and the Formation of Duty-Free Zones," Journal of Development Economics 26, 397-40.

World Bank (1992). "Export Processing zones." Washington: The World Bank. 